\title{
0 valor do Tempo. Dádiva e Voluntariado em Portugal em tempos de Crise
}

Antónia Pedroso de Lima*

Fernanda Maria Rivas Oliveira**

\section{Resumo}

Este artigo pretende discutir o uso do tempo como acto de acção moral num contexto de crise social. A partir da análise de práticas de voluntariado e entreajuda (formal e informal) emergentes em Portugal, veremos como essas práticas assentam em racionais de dádiva e reciprocidade, e são complexos processos que congregam fatores pessoais e espirituais, afectivos, morais e utilitaristas. $\mathrm{O}$ atual contexto de crise em Portugal tem vindo a fomentar o crescimento acelerado de associações e de grupos de diferentes dimensões e enquadramentos, que de forma solidária oferecem tempo próprio para assegurar algumas necessidades básicas (sejam bens essenciais ou companhia) aos mais necessitados. Considerando que esses processos têm vindo a alterar profundamente a relação indivíduo-Estado, defendemos que é fundamental analisar as novas formas de dádiva na reprodução social nas economias capitalistas, e que a dádiva de tempo assume um papel central por se constituir como valor económico, moral e social.

\section{Palavras-Chave}

Cuidado. Dádiva. Voluntariado.

\footnotetext{
* Antónia é PhD em Antropologia, professora e investigadora no Instituto Universitário de Lisboa/ISCTE-IUL, Universidade do Minho; e investigadora integrada do Centro em Rede de Investigação em Antropologia - CRIA, Lisboa, Portugal. E-mail: antonia.lima@iscte.pt.

** Fernanda Maria é mestra em Antropologia e investigadora no Instituto Universitário de Lisboa /ISCTE-IUL, Universidade do Minho; e pesquisadora colaboradora do Centro em Rede de Investigação em Antropologia - CRIA, Lisboa, Portugal. E-mail: rivas.fernanda@gmail.com.
} 


\title{
Abstract
}

This paper aims to discuss the use of time as a moral action act in the context of a social crisis. By taking into account an analysis of voluntary work and mutual assistance (formal and informal) which emerged in Portugal, we'll show how these practices are based on godsend and reciprocity, and that they are complex processes which bring together personal, spiritual, emotional, moral, and utilitarian factors. The current crisis context in Portugal has been promoting a rapid growth of associations and groups of different sizes and nature. In solidarity, these groups offer their own time to ensure some basic needs (whether they are essential goods or company) to people in need. Considering that these complex processes have come to deeply change the relationship between the individual and the State, we argue that it is crucial to analyze these new forms of godsend in the social reproduction of capitalist economies, and that the "donation" of time plays a central role because it presents economic, moral, and social value.

\section{Keywords}

Care. Godsend. Volunteer work.

\section{Apresentação}

\author{
"Ajudar os outros, olhe.. não sei explicar, \\ mas sei que me sinto bem a ajudar (...), \\ a gente ajuda, mas traz mais do que dá (...)". \\ Filomena ${ }^{1}$, multicuidadora.
}

Os processos de participação cívica e voluntariado têm crescido de forma exponencial nos últimos anos em Portugal. Esse crescimento está directamente relacionado com o contexto de crise, de abalo nos processos de reprodução social que assistimos em Portugal desde 2011, onde as práticas voluntárias de ajuda ao outro se tornaram fundamentais para assegurar o quotidiano de muitos. Esses processos de voluntariado assentam em dinâmicas de dádiva que

\footnotetext{
${ }^{1}$ Todos os nomes dos nossos interlocutores são fictícios, à excepção de um caso (nota de rodapé no 13 ).
} 
dizem respeito "ao bem-estar, à satisfação de todas as necessidades humanas (....) necessidades de bens públicos, tais como educação, segurança e um ambiente seguro, e ainda qualidades intangíveis, como a dignidade" (HANN; HART, 2011). Essas práticas são múltiplas e diversificadas e apresentam-se em forma material de circulação de bens fundamentais, mas, sobretudo, em disponibilização de tempo de ajuda solidária. Assim, partindo da reflexão sobre práticas de apoio social interpessoal e comunitário em Portugal que visam satisfazer necessidades daqueles que de outra forma não teriam como as resolver - iremos discutir a importância da dádiva no âmbito das economias capitalistas modernas. A reflexão será feita a partir de trabalho de pesquisa etnográfica realizada em Portugal (em particular nas cidades de Lisboa, Évora e Viana do Castelo), entre 2012 e $2015^{2}$.

Portugal, como outros países europeus, atravessa uma ampla situação de crise económica e social que promoveu um profundo abalo no modelo social, colocando em questão não apenas os mercados mas também as instituições, os modos de vida, e os processos de reprodução social, alterando significativamente as relações sociais e afectando quase todas as dimensões da vida quotidiana. ${ }^{3}$ Significa isto que, em resultado da aplicação das medidas de austeridade em face da crise da dívida soberana, a população viu afectadas as suas condições de existência e fragilizadas as suas expectativas em relação à sua vida e ao seu futuro. Presentemente em Portugal proliferam contextos de privação diferenciados, tributários de carências materiais e imateriais, que cresceram exponencialmente da população já empobrecida e se estenderam à classe média. A partir de 2011, verificou-se um declínio acentuado de alguns dos mais importantes sectores produtivos, de que resultou um valor recorde

\footnotetext{
${ }^{2}$ Este artigo resulta da investigação feita no âmbito do projecto "O Cuidado como factor de sustentabilidade em contexto de crise”, financiado pela Fundação para a Ciência e a Tecnologia FCT PTDC/CS-ANT/117259/2010, IR Antónia Pedroso de Lima. Parte da investigação foi a base da dissertação de Mestrado de Fernanda Rivas de Oliveira, cujo título é "Solidariedade, dádiva e mercados privados numa Comunidade Eborense: Sustentabilidade e processos constitutivos dos Agentes de Cuidado". Agradecemos aos colegas da equipa as discussões dos temas que aqui analisamos.

${ }^{3}$ A extensão do empobrecimento e privação material produzido pela austeridade numa "sociedade de bem-estar" (onde as pessoas dependem de redes sociais e apoio mútuo) contribuiu para um grande aumento das desigualdades sociais e alterou drasticamente as relações entre as gerações (cf. COLLINS, 2008; COLLINS \& MAYER, 2010). Os efeitos das medidas de ajustamento na vida dos cidadãos mostram cruamente o agravar dos mecanismos de desigualdade não só em Portugal, mas, como demonstra claramente Piketty, nas sociedades ocidentais capitalistas que estão em conformidade com as dinâmicas da economia-política capitalista contemporânea.
} 
de desemprego num momento de diminuição acentuada dos mecanismos de apoio estatais, empurrando grande parte da população para uma perda generalizada de acesso às áreas fundamentais da saúde, educação e trabalho, promovendo, assim, uma degradação acelerada dos factores gerais de bemestar.

Com a crise aumentou a percentagem de pessoas incapazes de fazer face aos seus compromissos financeiros e assegurar o seu dia a dia. A par dos trabalhadores pobres e dos desempregados de longa duração, há cada vez mais recém-desempregados. Nesses casos, recorrer à solidariedade familiar ou institucional e à partilha de recursos tornou-se a primeira, e principal, estratégia para assegurar a sobrevivência. À medida que se esgotam as possibilidades de apoio garantido pelas redes interpessoais, a promoção de estratégias alternativas, como o apoio dado pelas redes interpessoais ou por organizações não governamentais de solidariedade social, é uma realidade cada vez mais presente num país onde até há bem pouco tempo era pouco expressiva. Para fazer face à actual falência do Estado Providência, as pessoas retomam vias não estatais para assegurar o seu quotidiano, em que a solidariedade, a reciprocidade e a dádiva se consolidam em redes de voluntariado que crescem e se adensam à medida da progressão das carências. ${ }^{4}$ Num certo sentido, poderíamos dizer que estamos a regressar à definição de Portugal como uma "welfare society" propostas por oposição ao "welfare state" (SANTOS, 1993; 1999).${ }^{5}$ Dada a ineficácia do Estado no cumprimento das suas funções de apoio em situações de emergência, a sociedade de bemestar renova o seu vigor: reactivam-se redes familiares e vicinais, e emergem inúmeras organizações voluntárias de distribuição alimentar e de bens de primeira necessidade, proliferando organizações de apoio nos mais diversos domínios da vida social (jurídicos, financeiros etc.).

\footnotetext{
${ }^{4}$ Trabalhos de outros autores mostraram como em situações de quebra do suporte fornecido por um Estado fraco e incipiente, são atenuadas por redes de parentes e vizinhos que prestam assistência e cuidados a título pessoal, como mostram alguns (SANTOS 1993, HOCHSCHILD, 2004), ultrapassando assim situações críticas através de estratégias pessoais informais (BORNEMAN 2001; L'ESTOILE 2014).

${ }^{5}$ Essa ideia significa que os encontros entre cidadão e Estado são escassos em termos do apoio dado por este último, e que o Estado português não foi tanto erodido pela tendência neoliberal, mas pelo facto de os seus mecanismos de providência serem subdesenvolvidos; e que os encontros de "apoio" nas comunidades são abundantes graças à eficácia dos laços morais, redes de parentes e vizinhos que dão apoio económico e formas de cuidado e assistência), e onde as mulheres são actrizes centrais (cf. CUNHA, 2013).
} 


\section{Terrenos de voluntariado}

Os processos de participação cívica e voluntariado têm crescido de forma exponencial nos últimos anos em Portugal, oferecendo serviços em múltiplos domínios e abraçando um leque de necessidades muito alargado. Contudo, existe um elemento comum a todas essas práticas: a dádiva de tempo dos voluntários das associações, que disponibilizam o seu tempo pessoal de forma não remunerada para a realização de um serviço social.

ExistemhojeemPortugalincontáveisorganizaçõesinformaiseinstitucionais que assentam na entrega voluntária de tempo próprio para a realização de actividades de solidariedade social. Quer no caso das organizações de estrutura estatal, as IPSS (Instituições Particulares de Solidariedade Social) ${ }^{6}$, quer as organizações informais e sem assentamento institucional (ONG's, associações comunitárias etc.), organizam a sua operação na acção voluntária de cidadãos que doam tempo próprio, que é utilizado para a realização de trabalho nas organizações que dele necessitam.

O aumento real do voluntariado em Portugal nos últimos anos foi acompanhado de um processo de definição e enquadramento jurídico da acção voluntária ${ }^{7}$. Foi criado o Concelho Nacional para a Promoção do Voluntariado (CNPV) e Bancos Locais de Voluntariado, estatais, municipais e privados. A institucionalização dessas práticas e a consciência permanente de que há cidadãos em situações de grande carência e necessidade promoveram uma maior visibilidade desses processos, contribuindo, assim, para uma maior valorização social e política dessa prática. Disto foi exemplo o facto de o ano de 2011 ter sido o Ano Europeu do Voluntariado (AEV), fazendo proliferar em Portugal as iniciativas voluntárias sob essa égide e com base no lema Ofereça um pouco do seu tempo para ajudar a quem precisas.

\footnotetext{
${ }^{6}$ Essas instituições constituem-se por um conjunto de funcionários públicos que formam o corpo administrativo, mas os serviços prestados à comunidade (apoio à família, crianças e jovens; proteção de idosos; promoção saúde e educação; e resolução de problemas habitacionais) são operacionalizados por voluntários (para mais informação, consultar o lugar http://www4.segsocial.pt/ipss ).

${ }^{7}$ A seguir transcrevemos uma das principais conclusões de um estudo realizado pelo Instituto Nacional de Estatística em 2012. "Estima-se que, em 2012, 11,5\% da população residente com 15 ou mais anos tenha participado em, pelo menos, uma atividade formal e/ou informal de trabalho voluntário, o que representou quase 1 milhão e 40 mil voluntários”. Mais informações podem ser consultadas no lugar https://www.ine.pt/ine_novidades/semin/INEWS_n16/files/assets/basic$\mathrm{html} /$ page18.html.

${ }^{8}$ Para mais informações sobre o AEV, consultar http://www.aev2011.eu
} 
O nosso objectivo neste texto não é enumerar com rigor os números ou os no-mes das associações para demonstrar o crescimento exponencial desses processos. Para a discussão que queremos fazer neste artigo, iremos apenas abordar algumas das instituições com que trabalhamos: Banco do Tempo, Banco Alimentar Contra a Fome, Refood, C.A.S.A. Amiga ${ }^{9}$. Essas organizações têm várias delegações distribuídas pelo país e funcionam em rede, actuando sempre que possível através de outras como parceiras, potenciando e partilhando recursos.

\section{0 banco do tempo}

Uma das instituições mais ilustrativas da organização dessas dádivas em torno de uma estrutura formal é o Banco do Tempo que, em Portugal, funciona ao abrigo de uma organização de inspiração católica cristã, o Graal ${ }^{10}$. O Graal constituiu-se há 50 anos em Portugal com forte participação de Maria de Lurdes Pintassilgo e Maria Teresa Santa Clara Gomes ${ }^{11}$, sendo um movimento que está difundido por todo o mundo. Em Portugal define-se como um movimento internacional de mulheres, para uma cultura do cuidado. O Banco do Tempo é uma organização de voluntariado multifacetada que se apresenta da seguinte forma ${ }^{12}$ :

O Banco de Tempo é um sistema de organização de trocas solidárias que promove o encontro entre a oferta e a procura de serviços dispo-nibilizados pelos seus membros. No Banco de Tempo trocase tempo por tempo; todas as horas têm o mesmo valor e quem participa com-promete-se a dar e a receber tempo.

\footnotetext{
${ }^{9}$ O C.A.S.A. Amiga é uma IPSS subsidiária do C.A.S.A (Centro de Apoio aos Sem Abrigo), criada precisamente por motivo da crescente dificuldade de acesso a bens básicos por parte das famílias das comunidades onde o C.A.S.A actuava. O Banco Alimentar contra a Fome está integrado na Federação Europeia de Bancos Alimentares e a Refood e Banco do Tempo são organizações informais.

${ }^{10}$ Informação disponível em: http://www.graal.org.pt.

${ }^{11}$ Maria de Lurdes Pintassilgo foi primeiro-ministro em Portugal, estando em funções entre 1979 e 1980. As duas mulheres referidas estiveram ligadas a movimentos sociais de emancipação feminista e outros relacionados com o cuidado (com forte inspiração religiosa).

${ }^{12}$ A informação que se segue foi retirada do lugar do Banco do Tempo na Internet. http://www. bancodetempo.net/pt/BancoDeTempo/2.
} 
Na prática, funciona deste modo: quando um membro do Banco de Tempo precisa de um serviço, contacta a sua agência, que procura um outro membro que o possa realizar. Realizado o serviço, quem o solicitou passa um cheque de tempo. O membro que prestou o serviço deposita o cheque, que é creditado na sua conta, e poderá obter serviços disponibilizados por qualquer outro membro. Existem 33 agências bancárias em Portugal e a sua organização assemelha-se às estruturas empresariam privadas (reuniões de actividades periódicas com as agências para fazer pontos da situação e acompanhamento e gestão das actividades, horários predefinidos, etc.).

A instituição assume-se como um Banco, pois recebe activos (horas voluntá-rias), detém um passivo (horas a pagar, crédito dos seus associados) e transacciona capital (mão de obra voluntária). Por outro lado, as várias delegações existentes no país são agências, sendo o Graal uma espécie de órgão regulador central. O trabalho das 1900 pessoas que integram as diferentes agências do Banco do Tempo é simbolicamente operacionalizado por via da imitação do funcionamento de um Banco real. Trata-se por isso da produção de uma economia paralela simbólica e, de facto, orientada por noções colectivas de "utilidade social e do interesse colectivo", características das economias solidárias (LAVILLE, 2010).

A constituição de uma instituição totalmente performática ao ponto de se constituir como um Banco denota a incorporação de um simples acto de troca de serviços num universo de valor que, tendo uma significativa importância económica, centra a sua importância no valor moral, a troca de tempo para fins solidários. A operação que se realiza no Banco do Tempo é pensada em termos de serviços, mimetizando a gestão das instituições comerciais em que as dádivas de tempo expressas nos serviços prestados são pagas com cheques de horas. Nesses casos, a estrutura do Banco é formalizada, incorporandose, assim, valor simbólico ao serviço, para além do valor real e de facto que o serviço oferece aos beneficiários.

A agência com que mais trabalhamos foi a de Évora, sediada num primeiro an-dar de um prédio propriedade da Câmara de Évora. Aqui, a agência tem disponíveis múltiplos serviços, em que se destacam pintura de casas, jardinagem, costura, cozinha, ajuda nos estudos ou em contabilidade, a companhia de idosos e crianças. A sua mentora, a Prof ${ }^{\underline{a}}$. Amélia ${ }^{13}$, conta

\footnotetext{
${ }^{13}$ Nome real
} 
que vem de uma aldeia onde os vizinhos se ajudavam, sendo esse o estímulo inicial para a criação daquela agência e a esperança de restituição das relações de vizinhança. Sendo esse o princípio fundador do Banco do Tempo em Évora, refere que a actividade entre os sócios assenta em princípios activos de solidariedade e de confiança. Exemplos disto são os seguintes casos:

D. Alice está acamada há vários anos sendo cuidada em permanência pela filha. Sempre a filha tem de sair recorre ao Banco do tempo para o serviço de companhia da mãe até ela voltar. Um dos associados dis-poníveis fazia as horas necessárias e recebia um cheque da filha com o crédito de horas.

O Senhor João, que vive sozinho e tem dificuldades de mobilidade precisa sempre de acompanhamento para ir ao médico. As horas gas-tas pelo acompanhante eram pagas por essa pessoa através de um cheque com o crédito das horas.

Um dos associados preenchia os documentos de IRS $^{14}$ de quem não sabia fazê-lo, O tempo gasto era pago em cheque por quem solicitava esse serviço.

A professora Amélia refere que o Banco do Tempo é um projecto que a motiva muito, pois considera que é um "voluntariado diferente, é obrigatório receber por princípio. Para a pessoa não ficar em dívida nem com a pessoa que deu o trabalho, nem com ninguém”.

Explica-nos também que não é possível uma pessoa dar exclusivamente e não receber. "Eu, por exemplo, tinha na minha conta do Ban-co do tempo um valor muito elevado de horas que não sabia como gastar. Para ir gastando o "dinheiro" pagava servicos de apanha da fruta na sua casa ou a recolha de lenha para a lareira no inverno".

Para além das ajudas interpessoais promovidas dentro do Banco do Tempo, a agência de Évora é fortemente dinamizadora de relações interinstitucionais com o ob-jectivo de aumentar a capacidade de apoio e ajuda de todos os que dela necessitem. Assim, a par das parcerias assentes em relações de proximidade e vizinhança, geradas nas sociabilidades particulares

${ }^{14}$ IRS é o acrónimo de "imposto sobre o rendimento". Declaração anual que tem que obrigatoriamente ser feita pelos cidadãos nacionais que aufiram rendimento. 
dos voluntários, foram estabelecidas parcerias entre o Município, as Juntas de freguesia, o centro de saúde, a Universidade de Évora e o próprio Banco do Tempo. O caso mais exemplar do êxito dessas articulações institucionais diz respeito ao programa Laços para a Vida - Casa E Companhia, promovido pelo Município de Évora em parceria com a universidade de Évora, o centro de saúde e pessoas particulares. Trata-se de um programa que tem por objectivo conseguir habitação para estudantes universitários que não têm posses para pagar uma casa para morar enquanto realizam os seus cursos e, simultaneamente, conseguir companhia e ajuda para idosos que habitem sozinhos e tenham dificuldade de assegurar o pagamento das suas despesas. Em conjunto resolvem o problema de cada um: a principal responsabilidade do jovem é fazer companhia ao idoso, e este deve oferecer ao jovem um quarto (e um lar). As duas partes, idoso e universitário, realizam um contrato formal, consagrado pelo município e a universidade, que define as condições particulares de cada caso. Esse programa tem sido um enorme sucesso e já tem extensões noutras regiões do país.

Para que os idosos possam concorrer ao programa, é necessário que as suas ca-sas tenham condições de habitabilidade. Tratando-se de uma população envelhecida, isolada e com dificuldades financeiras, muitas vezes essas condições não existem e é através do Banco do Tempo que se consegue reabilitar as casas, permitindo, assim, a entrada dos idosos no Programa. Uma das casas que poderia ir a concurso, caso tivesse as condições para tal, era a casa da D. Margarida, uma idosa que vivia sozinha e queria receber um jovem universitário. Foi o Banco do Tempo a fornecer ajuda para a recupe-ração da casa que estava em muito mau estado, a cair. O arranjo da casa (pintura, alvenaria etc.) implicou um gasto de 900 horas ao Banco do Tempo, mas deixou a casa da D. Margarida em condições de receber o jovem.

Depois de o acordo estabelecido, cabe à Câmara acompanhar o processo e ga-rantir que jovem e idoso estão a receber e oferecer do e ao outro tudo aquilo que tinha sido preestabelecido. $\mathrm{O}$ acompanhamento desses processos no quotidiano dos agregados habitacionais é delegado pelo Município no Banco do Tempo. No caso da D. Margarida, era a própria Prof ${ }^{\text {a }}$. Amélia que realizava essa tarefa.

A parceria do Banco do Tempo com a universidade de Évora resolve também outros problemas, dado que o Banco do Tempo tem uma oferta de serviços especializada para a população universitária oriunda de outras zonas do país. Estes, diz a professora, porque estão sozinhos "podem necessitar de uma camisa lavada, ou mais importante ainda, de uma casa, de um jantar em 
família quando for preciso". O projecto maior que o Banco do Tempo tinha na altura da pesquisa era a reabilitação de um monte (pequeno conjunto de casas) em zona rural, tornando-o apto a receber um grupo de famílias sem abrigo. O Banco do Tempo está ainda a trabalhar com as escolas da cidade, criando novas colaborações, minibancos do tempo, através dos quais as crianças podem aprender a partilhar e a trocar pequenos serviços escolares entre si e a confiar na ajuda dos outros para resolver problemas. As redes que trabalham em parceira com essa instituição são múltiplas e variadas e mostram bem o valor da dádiva de tempo pessoal num processo de solidariedade em que a dádiva e a reciprocidade se tornam elementos estruturantes da vida social e assumem um papel central nos processos de reprodução social.

\section{Associação Coração Amarelo}

A Associação Coração Amarelo (ACA) é uma IPSS que tem várias delegações no país e cuja missão original é oferecer companhia aos mais idosos da comunidade. O caso que melhor acompanhámos foi a delegação de Oeiras (região de Lisboa). Em Portugal, o envelhecimento da população nacional é resultante da convergência de alguns factores ${ }^{15}$, sendo hoje um importante problema demográfico e social. Na região de Oeiras (periferia de Lisboa), verifica-se uma perda acentuada de qualidade de vida em grande parte das zonas populacionais mais carenciadas (bairros sociais, zonas urbanas periféricas), com particular incidência nos grupos de idosos. A delegação da ACA na zona teve como propósito fundador acompanhar os idosos em situação de solidão. Contudo, a abrangência da sua ação aumentou consideravelmente nos últimos anos à medida que se alargavam as necessidades da população de que cuidavam. A operativa da associação assenta na dádiva de tempo por parte dos voluntários, que visitam periodicamente os seus utentes. O objectivo das visitas é a oferta de um momento qualitativamente diferenciado para o utente, embora, como se pode ver através de alguns casos concretos, a tarefa acaba por ser muito mais abrangente do que isso.

\footnotetext{
${ }^{15}$ Em Portugal verifica-se a diminuição abrupta das taxas de fecundidade e de natalidade (com valores particularmente reduzidos a partir de 2012). Por outro lado e do ponto de vista global, os avanços médicos e das tecnologias da vida têm vindo a promover o prolongamento da duração da vida humana. A recessão económica é também e localmente um factor a considerar na diminuição da natalidade em Portugal nos últimos anos.
} 
D. Teresa é uma mulher de 67 anos, residente em Carnaxide. Tem formação su-perior em Gestão, trabalhou na indústria farmacêutica, numa multinacional onde diz ter ganho muito dinheiro. Depois de instalada a recessão económica em Portugal, a empresa sofreu profundas mudanças, e ela foi dispensada. De modo resiliente, D. Teresa abriu uma empresa própria e continuou a ganhar muito dinheiro, como refere, na área imobiliária. Porém, a crise desse sector abalou a sua actividade e ela teve que deixar os negócios e fechar a empresa. Durante esse mau momento surgiram outros factores pessoais, também eles desfavoráveis, que a empurraram para a reforma antecipada. Hoje tem problemas graves de saúde que reduzem a sua mobilidade, tendo inclusivamente grande dificuldade em falar. Perdeu de modo destrutivo a sua autoestima e deixou de "poder cuidar de si", como refere frequentemente.

A acrescer a essas dificuldades, cuida de dois netos desde pequenos, que tinham à data da pesquisa 14 e 15 anos. Consigo mora também uma filha de 47 anos, doente e fortemente dependente ${ }^{16}$. A mãe dos netos da D. Teresa tem 45 anos, vive com um namorado, visita a mãe e os filhos, mas abandonou o seu papel de progenitora, deixando os filhos totalmente ao cuidado da D. Teresa, divorciada. A sua relação com o ex-marido era pouco positiva, embora cordial sempre que se tratava de algo que tivesse a ver com as filhas. Quando o ex-marido morreu, sentiu um "vazio", diz ela, pois “apesar de não sermos próximos, parece que eu tinha ali um apoio".

O caso da D. Teresa está atravessado por factores de perda de qualidade de vida, que passam pela diminuição acelerada da sua saúde; pela imposição de uma obrigatoriedade de cuidado familiar em permanência (da filha e netos, jovens adolescentes e uma pessoa com doença grave); e por um conjunto de factores psicológicos destrutivos da sua autoestima de tipo depressivo, ao que se acresce um forte sentido de infelicidade e desinteresse geral. O momento das visitas, que por vezes chegavam a ser tardes inteiras, é fundamental para assegurar uma melhoria pontual (embora se espere possa vir a ter efeitos mais prolongados) do seu estado anímico profundamente abalado. Neste caso, a dádiva de tempo associada às visitas regulares da voluntária têm uma

\footnotetext{
${ }^{16}$ A filha sofre de um problema neurológico, degenerativo, conforme explicação da voluntária que acompanha D. Teresa. Essa condição de saúde da filha da D. Teresa traduz-se numa dependência muito elevada de cuidado clínico próximo e de um acompanhamento familiar constante, neste caso, da mãe.
} 
centralidade estabilizadora da vida da D. Teresa, pois sem a voluntária ela sentir-se-ia "sempre perdida e só".

Neste caso, os factores de desordem geral da sua vida (obrigações impostas de modo muito violento) recuperam alguma ordem por via do encontro com o voluntário. Essas visitas têm de algum modo a função de catarse, estando a voluntária que a visita ciente da sua importância.

Outro dos casos que acompanhámos com maior atenção é o da D. Maria, uma mulher de 91 anos, que ouve mal e tem marcas significativas de degradação física e corporal. Vive sozinha num bairro social em Oeiras, está lúcida e mantém um nível cognitivo e de raciocínio muito elevado para a sua idade e condição. Essa mulher recebe com frequência indeterminada a visita de voluntárias da ACA. A voluntária que acompanha há mais tempo essa mulher é a própria responsável da agência de Oeiras, que gere a relação com a D. Maria como se de um familiar seu se tratasse. Conhece as suas necessidades diárias de higiene, o que diz respeito à limpeza da casa, e acompanha todos os aspectos de saúde e clínicos da sua utente. Hoje trata de garantir que todos os domínios da vida da D. Maria estejam supervisionados. A voluntária tem a chave da casa da D. Maria, e com a frequência necessária vai lá tratar de algum aspecto doméstico que tenha que ser resolvido. Por exemplo, desloca-se (ela ou outro voluntário em sua substituição) à casa da Maria para deixar num lugar da casa definido para o efeito um conjunto de revistas cor-de-rosa, pois o "grande entretenimento dela é a leitura", refere a voluntária.

O caso da D. Maria ilustra bem a importância da dádiva de tempo enquanto provedor de afectos e companhia, tão necessários no caso de uma mulher de 91 anos que vive sozinha e sem família ou amigos por perto. $\mathrm{O}$ nível de preocupação e familiaridade que a voluntária tem com a D. Maria atribui à dádiva de tempo um valor moral inestimável. Vejamos uma conversa que registámos numa nota de campo:

\footnotetext{
V: Lavou a cabeça, lavou D. Maria?

M: Lavei, lavei, estava a precisar.

V: Ainda tinha champô? ["ela tomou banho comigo há uns dias", sussurra-me a voluntária ao ouvido]

M: olha... [diz rindo], não tinha. Foi com água e sabão que é muito bom!

V: mas havia lá um (frasco) atrás cheio. O que não tinha quase nada eu deitei fora e ficou um cheio, lembra-se?
} 


\section{[A voluntária levanta-se e vai à casa de banho]}

M: já não funciono a $100 \%$ totalmente [diz rindo a D. M enquanto estávamos sós]

[A voluntária regressa com 2 frascos de champô e diz apontando para os frascos: "1, 2, cheio, está a ver como eu tinha razão?"]

Continua a conversa do champô e avança:

M: ela sabe muito bem, ela trata muito bem de mim. Mas eu quis to-mar banho e tomei! [rindo]

V: Qualquer dia vamos ao baieta ${ }^{17}$. Vamos ao cabeleireiro. Para o Na-tal.

M: Para o Natal não, para mim! [risos]

Apesar de apresentar um estado mental saudável, D. Maria carece de ajuda para os cuidados de higiene e outros, embora insista na sua autonomia, facto que muito ale-gra a voluntária, que a promove sempre que isso não afecte a segurança da idosa. Ainda assim, não consegue fazer sozinha o cuidado ideal da casa e/ou do seu próprio corpo e mente (considerando a sua idade). D. Maria é um caso de solidão que não tem o acompanhamento devido por parte das instituições assistencialistas do Estado, para além do processo "higienista medicalizado" (ELIAS, 1982) básico, que é, no seu caso, a assistência médica num Centro de Saúde. As necessidades da D. Maria estão muito para além do acompanhamento clínico. O acompanhamento dado pela voluntária abrange outros domínios da vida, tão fundamentais à vida como é aquele. A relação afectuosa é, nessa fase, recíproca pois elas experimentam a relação como se de uma relação familiar se tratasse. Essa relação oferece condições de humanidade para além das que a D. Maria teria acesso e que muito evocariam as noções de "mera vida" (AGAMBEN, 1989; FASSIN, 2010). São precisamente os pequenos factores de humanização da tarefa de cuidar, as minúcias que a relação oferece, que fazem a diferença entre o humano e o indigno. A cuidadora voluntária torna-se "da família" através da reversibilidade da dádiva. $\mathrm{O}$ afecto embrenha-se na execução das tarefas, a moralidade reveste a obrigação. O depósito, sem falhas, de revistas cor-de-rosa em casa da D. Maria, oferece-lhe a possibilidade de vivenciar uma condição humana mais digna para além das necessidades básicas da vida. A leitura das notícias da vida social dessas revistas é um factor que acresce valor

${ }^{17}$ Expressão popular para cabeleireiro. 
à vida da D. Maria, pois a entretém (ocupa a mente e a mantém actualizada). Esse facto é reconhecido pela voluntária, executando as acções necessárias para que esse momento de lazer e de manutenção de uma mente activa não deixe de existir.

A ACA tem hoje uma actividade muito mais abrangente que a oferta de tempo para combater a solidão. Transcende a restrição etária e a problemática fundadora, sendo muito variado o tipo de serviços prestados pela associação. Os voluntários substituem-se em muitos casos (como se ilustrou nos casos anteriores) à pessoa ou às famílias, resolvendo questões quotidianas, como a realização das compras, ou a recolha de comida nos bancos alimentares, o acompanhamento ao médico, e a resolução de problemas burocráticos ou administrativos (gestão das finanças, pensões etc.).

A análise desses exemplos é de grande relevância para a reflexão que queremos fazer sobre a oferta de tempo próprio dos voluntários, enquanto dádiva com um valor profundamente altruísta, moral, mas cujos resultados têm valor instrumental, pois resolvem, de facto, problemas ou necessidades que não tinham solução institucional.

Os casos apresentados ilustram bem a importância da dádiva de tempo enquanto elemento fundamental de sustentabilidade geral da vida daquelas duas mulheres. Tanto o caso da ACA como do Banco do Tempo mostram como o cuidado prestado ao outro, através do voluntariado em instituições solidárias de apoio social, desliza numa espécie de continum, tendo nos extremos dois tipos ideais de cuidado. Num extremo encontramos o cuidado como afecto puro (com base na compaixão pura e no amor ao próximo, totalmente altruísta), e no extremo oposto o tipo mais instrumentalista (que visa atingir objectivos totalmente egoístas) de cuidado. O mais frequente é encontrarmos práticas mistas que se situam entre esses dois polos, a obrigação com afecto (dever e carinho), e outros, como sejam os serviços de proximidade realizados no âmbito das organizações solidárias. Os voluntários que acompanhámos no ACA aproximam-se do tipo misto, cuidando imbuídos de um dever moralmente informado que se vai construindo num afecto puro à medida que vão criando relação com as pessoas de quem cuidam. Essa ideia da satisfação moral implícita na ajuda ao Outro e a reciprocidade serão desenvolvidas na secção seguinte. De momento podemos concluir que a dádiva na forma de tempo e que se corporiza numa multiplicidade de servicos ou tarefas realizadas com e para o utente é, nesses casos, fundamental para uma existência dignificante e estruturalmente sustentada, tanto para o voluntário como para o utente. A lógica da reciprocidade aprecia-se na 
satisfação pessoal, constante e progressiva do voluntário, que se sente família, e uma pessoa fundamental na vida do seu utente. Exploraremos melhor a seguir a ideia.

\section{Refood, CASA e Banco Alimentar}

Se em Portugal existem inúmeras organizações voluntárias que atuam nos mais diversos domínios de necessidades, verifica-se o crescimento exponencial de organizações que se dedicam à distribuição de cabazes alimentares. Algumas destas, já referidas aqui no início do texto, são a Refood e o C.A.S.A. Amiga, e detêm uma importância fundamental na vida de algumas famílias que levam para casa diária ou semanalmente cabazes de alimentos.

Nessas organizações, com sucursais por todo o país, os voluntários recolhem a-limentos excedentários doados por restaurantes, supermercados e particulares, reúnem-nos em instalações próprias (doadas ou emprestadas por privados ou municípios) e os entregam aos utentes. As agências que melhor conhecemos no terreno (várias e em diferentes pontos urbanos e periféricos) juntam um elevado número de voluntários e de equipamentos (instalações, equipamentos de cozinha e embalagem etc.) e ajudam um número muito significativo de famílias que vão, conforme as suas necessidades, buscar a comida confeccionada e alguns bens de mercearia doados normalmente pelo Banco Alimentar e pelos grandes hipermercados.

Vejamos o caso da Paula, beneficiária da Refood, através de um recorte de uma das conversas com ela:

P: Onde é que está o problema mesmo desta sociedade? O problema está que eu tenho mais de 50 anos. Tenho. Tenho 54 e portanto, e o meu curriculum é... demasiado bom!

$\mathrm{I}^{18}$ : Mas trabalhava?

P: Trabalhei. Trabalhei toda a vida. Fiquei [desempregada] por uma situação muito ingrata que foi a empresa onde eu estava faliu. A directora foi-nos escondendo a falência até à última. E na última disse-nos que não tinha dinheiro para nos pagar indemnizações

${ }^{18} \mathrm{O}$ "I" deve ser lido como "Investigador". 
e ou nós assinávamos o contrato com uma nova empresa que nos tinha comprado a marca, o logotipo... E nós nesse momento, 3 ou 4 de nós estávamos já com uma grande depressão. Foi há uns anos bons. Já foi há 4 .

I: Ahh... Foi agora portanto, foi a crise. Estamos a falar deste período [de crise]?

P: Sim, sim, estamos, estamos... E assinámos todo o contrato. Está-vamos todas a antidepressivo. Quando começamos a falar percebemos que estávamos todas a antidepressivo.

I: Mas por quê?

P: Porque víamos que não tínhamos clientes!... E, portanto, não somos burras, éramos todas mães de família com crianças a cargo e... [tem 2 filhos, um acabou os estudos, vive com dificuldades com a namorada, e está com frequência em casa da Paula. O outro ainda nem sequer entrou para a faculdade. Têm 26 e 18 anos, respectivamente].

P: Portanto, assinámos todo o contrato com promessas de... e ao fim de 5 meses estávamos todas na rua. Fomos todas corridas. Foi um es-quema financeiro para a empresa da patroa não entrar em falência mesmo, técnica, e empandeirou-nos todos. Essa nova empresa tratava-nos mal, mal, mal, mas mesmo mal que era para nos irmos mesmo embora. Então eu fiz um projecto enorme, que eles precisavam de mim, e eu adorei fazê-lo, que foi organizar as "conferências do Estoril". São conferências de 3 dias com políticos que eu adorei. Mas acabou. Mas mesmo no desemprego fui sempre fazendo coisas, ajudei em projectos, em gestão.

(...)

P: Recebi 4 anos de subsídio de desemprego. Pela idade como eu ti-nha, 50 já eram 3, e depois 1 mês por cada 5 anos de descontos. Como eu tinha muitos anos foram quase 4 anos. Agora recebo 419 [subsídio de desemprego subsequente] que acaba em dezembro [isto é $€ 320+€ 100$ aproximadamente, por ter um filho a estudar]. Esse valor dá para pagar a prestação da casa. O resto é daqui que eu tiro.

Outro casal que acompanhámos na nossa pesquisa é a Lídia e o Manuel (39 e 43 anos, respectivamente), têm 3 filhos de 16, 13 e 12, e estão actualmente a viver em Inglaterra, pois emigraram por terem chegado a uma situação de total falência financeira (partiram a 15 de setembro de 2015). O Manuel é licenciado em gestão pelo ISEG $^{19}$ e a Lídia tem o $10^{\circ}$ ano. Viveram de forma

\footnotetext{
${ }^{19}$ Instituto Superior de Engenharia e Gestão, Lisboa.
} 
muito abastada, pois o Manuel teve uma empresa de construção com o pai, com mais de 30 funcionários. Hoje não recebem nenhum tipo de subsídio, dado que o Manuel era empresário em nome individual e o seu regime tributário não lhe dava direito a receber subsídio. Por seu lado, a Lídia trabalhou no Bingo da Amadora ${ }^{20}$, que faliu, e ela ficou no desemprego. Recebeu subsídio de desemprego durante um período, mas já findou esse tempo. Ele faz biscates $^{21}$ quando aparecem, e ela distribui panfletos de publicidade sempre que surge a oportunidade. Vão semanalmente ao C.A.S.A. buscar géneros alimentares, mercearia, frutas e legumes, comprando unicamente peixe e carne para a alimentação da família.

Esses casos mostram a importância que a ajuda alimentar institucionalizada (no último caso) e informal (no primeiro) tem na gestão das necessidades alimentares da família. Os utentes saem das instalações do C.A.S.A frequentemente com sacos a transbordar de comida, pois, em grande parte do tempo da pesquisa, verificou-se que o stock alimentar para distribuir era enorme. O discurso de necessidades é comum aos utentes dessas organizações, que saem muito agradecidos com a instituição e com eles (voluntários).

O tempo oferecido pelos voluntários resulta, neste caso, na dádiva de "mãos para trabalhar", expressão corrente numa das delegações da Refood. Efectivamente e considerando a enorme quantidade de comida que precisa de ser acondicionada, congelada, separada e distribuída com rígidas normas internas ${ }^{22}$, são muitas "as mãos que são precisas para trabalhar". Ao contrário do caso da D. Maria e da D. Teresa, a relação com os utentes nessas

\footnotetext{
${ }^{20}$ Cidade periférica de Lisboa.

${ }^{21}$ Termo popular para definir trabalhos pontuais, sem vínculo contratual, com a duração temporal de dias.

${ }^{22} \mathrm{Na}$ Refood, a organização interna é semelhante à organização de uma empresa comercial. Tem gestores, chefes, e funcionários operacionais. A dinâmica é tipicamente empresarial, e a preocupação com as necessidades particulares de cada unidade familiar que apoiam é, em grande parte dos casos, muito significativa. Em todas as delegações da Refood existe 1 quadro de parede onde se transcrevem os dados principais das famílias. A informação sobre cada uma é detalhada, existindo fichas muito bem elaboradas de cada uma daquelas. Todas as famílias têm um número que identifica o saco(s) dessa família. Nesse quadro aparecem os nomes, o número de pessoas do agregado, o número de crianças e o número de idosos. Para além dessas informações aparecem as restrições alimentares (diabéticos, doenças relevantes etc.). É com base nessas informações que os voluntários enchem os sacos, garantindo que o seu conteúdo satisfaça e se adapte às necessidades dos beneficiários.
} 
instituições é mais pragmática e menos afectiva, embora muitas vezes é junto desses voluntários que os utentes pedem ajuda para outras necessidades emergentes (contactos para lares, creches, cunhas para médicos de especialidade, e muitos outros). Esses pedidos são por vezes resolvidos pelos voluntários que se envolvem pessoalmente com os problemas dos utentes, conseguindo através do seu interesse e empenho soluções para alguns casos: p.e., como aconteceu numa das delegações que conseguiu cursos gratuitos de capacitação profissional, garantindo assim empregos para alguns dos utentes e participantes nos cursos.

Nesses casos, a dádiva de tempo assenta numa lógica de reciprocidade, que é a resolução dos problemas imediatos dos utentes que se deslocam às instituições em situações de aflição. Neste caso, os conteúdos morais da acção voluntária assentam na disseminação de uma nova causa, na prossecução de um mundo melhor, que passa por ser mais justo e eticamente engajado. Hoje, a missão da Refood (que na sua origem era a de "desperdício 0"23), está muito mais orientada para um ímpeto moral de ajuda e de satisfação das necessidades dos mais desfavorecidos. Concomitantemente é também isso que os voluntários esperam quotidiana e constantemente receber: o reconhecimento activo de uma colaboração humanitária em prol da melhoria de vida daqueles que a eles recorrem.

\section{Cuidado: disposição motivacional para exprimir ideologias morais do bem e do justo}

Como vimos, a dádiva de tempo utilizada para o cuidado do outro em necessidade tor-na-se central para assegurar o quotidiano de muitos. Nas palavras de uma das nossas interlocutoras, "cuidar é mostrar que as práticas comuns do quotidiano podem ser me-canismos fundamentais de ajuda e ao mesmo tempo de autossatisfação". Tarefas de cuidado de saúde e integridade física, como as já descritas, mas também tarefas familiares simples, como

\footnotetext{
${ }^{23} \mathrm{O}$ objectivo fundador era a diminuição do desperdício alimentar, tendo como objectivo último garantir que nenhum alimento era desperdiçado nas comunidades. Hoje, o projecto está muito mais orientado para a missão humanitária, para um discurso de "amor". É assim que uma das coordenadoras de uma das delegações da Refood se refere à acção da organização, dizendo que é um discurso "do positivismo, de ser necessário resolver, do carinho pelos beneficiários e pela dedicação dos voluntários".
} 
cuidar dos netos ou ir buscá-los à escola, cozinhar ou realizar as tarefas domésticas menores (pequenos arranjos de costura, pinturas etc.), receber os filhos em casa, ou ajudá-los a manter a sua autonomia em momentos de dificuldade, pintar a casa de um vizinho, ajudar jovens do bairro nos estudos, são formas de cuidado fundamentais para a garantia da viabilidade do quotidiano de muitos dos nossos interlocutores no âmbito da pesquisa. Os gestos simples reinterpretam-se nas experiências de vida em situações de precaridade, tornando-se elementos centrais à sustentabilidade social.

É, portanto, frequentemente através da metáfora do "cuidado" que são expressas as disponibilizações para dar tempo para ajudar os outros e as preocupações morais acerca de uma existência ideal num mundo com desigualdades profundas e pessoas necessitadas.

As diferentes motivações na base da prática da dádiva no voluntariado podem ser pensadas a partir da teoria da dádiva de Mauss. Esse autor defende que o acto de dar associa simultaneamente valores de solidariedade, altruísmo e interesse. Na verdade, a dádiva não corresponde apenas a bondade e prossecução do bem e do moralmente correcto. Na nossa pesquisa, verificamos com frequência que, através da generosa disponibilização do tempo para cuidar, da dádiva expressa no voluntariado, as pessoas procuram uma recompensa simbólica para a sua própria existência, uma realização pessoal alcançada através do apoio dado ao próximo. Uma motivação moral de compaixão pelo outro. Como mostra Graeber, Mauss estava interessado na identificação dos princípios morais potencialmente presentes na troca em todas as sociedades (GRAEBER, 2001).

Voluntariado e altruísmo são considerados muitas vezes parte integrante de um mesmo processo. Porém, quem faz algum tipo de voluntariado e, portanto, dá gratuita-mente parte do seu tempo para cuidar, para agir em prol dos outros, tem um retorno, uma recompensa, que não é monetária, mas é moral. Por outras palavras, há uma consequência para o sujeito que não é exclusivamente ou unicamente dedicada ao outro, algo que poderia traduzir-se como: "Eu faço o bem e sinto-me bem. Eu acho que me tornei uma melhor pessoa e a quem estou ajudando mais é a mim mesma. Eu dou comida ao Banco Alimentar, eu dou sopa aos pobres mas ganho auto-estima, sensação de dever cumprido”. Pensar que essa ideia do amor ao outro não é generosidade pura torna a questão que analisamos mais complexa e interessante. Todo o voluntariado apresenta características muito semelhantes com ideais religiosos, e no contexto português esse é um aspecto que não pode ser descurado, pois a ideia da caridade é aqui um forte referente 
cultural. Esse processo tem uma faceta de generosidade, de compreensão pelos problemas e dificuldades alheias, mas tem a tal recompensa moral para o sujeito que, de certo modo, se salva a si próprio.

Retomemos a observação da professora Amélia para endereçar esta questão: "é obrigatório receber por princípio. Para a pessoa não ficar em dívida nem com a pessoa que deu o trabalho, nem com ninguém”. Tratase de um incentivo à devolução da dádi-va, permitindo a quem recebe a possibilidade de devolver (retribuir) a oferta. Essa é a lógica proposta por Mauss na análise do potlach. A ideia subjacente no caso dos Kwa-kiutl, segundo Mauss, era de algum modo inferiorizar o receptor da dádiva obrigando-o a manter-se num estado de devedor, facto que só era revertido quando o receptor se tornava dador. Naquele caso tratava-se de uma dinâmica circular, infinita e de algum modo paradoxal, que é a lógica da dádiva/contra-dádiva. No caso do Banco do Tempo de Évora, a reciprocidade expressa-se de igual modo na obrigatoriedade de receber as horas que se oferece, embora a ideia da subjugação pela interiorização (da dádiva), ou da ascensão na escala social não esteja presente. Neste caso não se trata de adquirir estatuto ou inferiorizar o receptor, mas antes de conseguir a salvação para si próprio. Esse processo mental é concomitantemente muito próprio das retóricas católicas salvacionistas, que muito inspiram, como dissemos, a prática voluntária em Portugal.

O valor da dádiva materializada em actos de cuidar do outro decorre das ques-tões de moralidade e ética que envolvem a avaliação dessas práticas e as associam à ideia de Bem, de Amor e de família.

Por outro lado, o trabalho de cuidar por estar associado ao afecto, ao laço emo-cional com o outro, surge frequentemente como pouco importante do ponto de vista económico ou social. Porém, neste novo momento histórico em que o contrato social se alterou, o cuidado tornou-se uma questão central.

Esta é, aliás, uma discussão importante no âmbito dos estudos sobre o cuidado. Em Portugal, como noutros países do sul da Europa com uma raiz cultural marcadamente católica, cuidar dos familiares é visto como uma obrigação moral (READ, 2019; GUIBERT, 2013; LIMA, 2015a) resultante do amor construído pela voz do sangue. Em consequência, quando alguém recebe um salário para tarefas de cuidado, é suposto que desenvolva também uma relação de afectividade e proximidade que a assemelha a alguém próximo, pois, como nos disseram, "só quem ama cuida tão bem". A tríade família/cuidado/afecto é, portanto, profundamente abalada quando envolve troca de dinheiro num contexto cultural em que amar é cuidar. $\mathrm{Na}$ 
família cuidamos (por amor e obrigação moral) de quem já cuidou de nós num processo de reciprocidade diferida, numa teia de dádivas de tempo e atenção e amor que se retribuem no tempo ao longo das gerações familiares. No trabalho voluntário de cuidar, no qual se performatiza a relação altruísta do cuidado desinteressado, a reciprocidade é atingida com a obtenção da satisfação pessoal intrínseca, da realização ao fazer o bem ao outro, numa relação de tipo familiar.

No entanto, é preciso ter em conta que as trocas de ajuda entre pessoas próximas ou entre desconhecidos mediados por instituições não podem ser reduzidas a uma forma de reciprocidade generalizada em que o dador recebe algo em troca, seja em bens materiais seja em bens espirituais. Não são actos calculados de ganhos para uns ou outros. Na verdade, nem sempre a ajuda prestada num momento é suposta ser retribuída. Ela é simplesmente um acto de atenção ao outro, de cuidado, de simpatia ou de compaixão, que é constitutivo da relação. Nos relatos dos nossos informantes, vemos bem que os actos de generosidade e solidariedade são levados a cabo sem sentimento de obrigação ou dever, mas são motivados por um conjunto de valores morais de responsabilidade pelos que lhes são próximos ou pelos seus concidadãos. Enquanto encontramos em quase todas as pessoas uma clara disponibilidade para ajudar familiares e pessoas próximas, o mesmo não acontece em relação à ajuda a desconhecidos em organizações de voluntariado. A obrigação moral associada aos laços de parentesco é forte, enquanto que a ajuda a estranhos é mais diluída e implica uma articulação entre defesa de ideal e disponibilidade. As lógicas subjacentes ao mesmo acto são, portanto, distintas, dependendo da relação preexistente com a pessoa em necessidade.

Não é, todavia, o conteúdo do valor moral, mas sim a nossa relação com a pes-soa, que altera a decisão da dádiva. Essas diferentes formas de dádiva dependem, por-tanto, de diferentes tipos de socialidade. Como refere Kelly a propósito do extraordinário livro de Han sobre o cuidado,

a disposição para ajudar as outras pessoas (não está) simplesmente assente na identificação emocional, Em vez disso (...) pelo menos o cuidado dos parentes e ao desejo de ser infinitamente disponível, e a uma abertura para as formas de sociabilidade que o futuro pode oferecer. Por vezes (...) o peso da responsabilidade pode ser demasiado ou muito abstracto. De facto, este é o problema que o livro de Han aponta sobre a problemática que é ao mesmo tempo 
etnográfica e moral: o balanço entre o contingente e o abrangente na capacidade de cuidar (KELLY, 2013, p.216).

Esse tipo cada vez mais amplo de acções de partilha, oferta e troca de bens e serviços deve ser, portanto, avaliado à luz de um novo paradigma. É muito importante termos consciência política de que, se por um lado essas estratégias informais de suporte aos sectores mais enfraquecidos da sociedade tornam a vida de quem deles beneficia possível em situações de crise e incerteza, elas são também centrais para todo o sistema social, pois inibem, até um certo ponto, a escalada da tensão social e do colapso económico individual e colectivo. Assim, consideramos que é fundamental incorporar num mesmo quadro de análise cuidado, economia e Estado, na medida em que essas dimensões se constituem, em conjunto, numa renovada economia moral com forte expressão nos quotidianos.

A ajuda voluntária não assenta na lógica do mercado capitalista, mas numa relação de dádiva, ou numa forma especial de troca económica (GRAEBER, 2010), que está para além da escolha racional assumindo (também) um valor de mercado, simultaneamente afectivo e financeiro, moral e social.

Em suma, é muito importante chamar a atenção para o valor económico das múltiplas e diferenciadas práticas solidárias de cuidar do outro que apresentámos, estabelecido através de trocas solidárias que respondem a necessidades, estando ou não os agentes (receptores e dadores) directamente envolvidos nas transacções. Significa que a circulação de bens, tempo e serviços de proximidade, dinamizados local e comunitariamente, mostram um sistema de trocas num regime de dádiva, central na vida e reprodução de uma economia moderna e capitalista e que contribuem decisivamente para a sua sustentabilidade. $\mathrm{O}$ valor do tempo disponibilizado pelos voluntários, seja em instituições, seja em redes interpessoais, ganha, assim, uma importância que articula afecto, consciência social, economia, moralidade e simbolismo que, no seu conjunto, são constitutivas de formas particulares de socialidade.

\section{Acção e intencionalidade da dádiva: moralidade e valor}

A acção social é informada por valores mas, simultaneamente, ao constituirse também cria valor. Valor económico - ao superar as carências de quem 
necessita (seja de bens materiais ou imateriais centrais à sua existência quotidiana); valor simbólico - ao praticar o bem; e valor moral - ao tornar-se melhor pessoa através da dádiva desinteressada.

Se é através da acção que a dádiva e o cuidado ganham significado, importa discutir a centralidade da agência humana no universo da ajuda voluntária, que não assenta numa lógica de mercado, mas antes numa relação de dádiva, ou numa forma especial de troca económica, o "comunismo", assim designado por Graeber (2010). Esse autor distingue três formas fundamentais (tipos ideais) de transacções económicas. O "comunismo", uma delas, opera, citando as palavras do autor, no "princípio de quem de acordo com as suas habilidades, para aqueles de acordo com as suas necessidades" (GRAEBER, 2010, p.4). Assim, o autor atribui ao termo um valor polissémico e, para este efeito, desconsidera o significado que diz respeito ao sistema de organização política, utilizando a palavra como uma forma económica, sinónima de "solidariedade, "ajuda mútua", "convivialidade”" ou até “"ajuda” (Ibidem). Nesse sentido, o universo agencial que esse tipo de relação de ajuda cristaliza deve ser pensado em termos de uma dinâmica de entrega daquilo que alguém está habilitado a oferecer, por exemplo, e, neste caso, tempo, em função das necessidades particulares de quem necessita. Trata-se, por isso, e também, de uma relação (meta) económica, pois pode ser pensada à luz de um economia humana afastada das propostas neoclássicas que pensam o indivíduo como uma entidade movida por escolhas racionais, assentes na aferição de custos e benefícios, procurando em exclusivo o interesse próprio.

O pensamento evolucionista defendia que a invenção das tecnologias de merca-do como o dinheiro ou a mais-valia resultante da transacção comercial dizia respeito às sociedades modernas. No caso das sociedades pré-modernas, os domínios do económico e do social fundiam-se, não se distinguindo a economia como um domínio autónomo. Verificando a inconsistência dessa ideia com os dados empíricos, Marcel Mauss defende a "diversidade das transacções económicas" e mostra que quer o dinheiro quer o cálculo de interesse (juro) não estavam ausentes nas sociedades arcaicas, aliás como se pôde até observar na instituição do potlach (MAUSS, 2008). Os pressupostos da teoria económica neoclássica assentes na racionalidade e nas motivações individualistas foram assim fortemente questionados. A ação humana mobiliza diferentes elementos motivacionais para além dos instumentalistas, como se tem vindo a explanar aqui. Deste modo, o voluntariado pode ser pensado no âmbito dessa diversidade das transações económicas, envolvendo factores de interesse com os morais e simbólicos. 
A antropologia económica das últimas décadas tem vindo a desconstruir algu-mas das dicotomias centrais da relação económica de mercado monetarizado (NA-ROTZKY; SMITH, 2006; GRABER, 2010; HART 2010). Tambémolegado daEco-nomia Feminista ofereceu importantescontribuições sobre o mito da dicotomização do mundo dos afectos e do mercado, do público e do privado, ou de outra forma, da natureza e da cultura (FOLBRE; NELSON, 2000; NELSON 2005; ORTNER, 1974; LIMA, 2015). Defendemos que as motivações que informam a acção voluntária e de solidariedade dizem respeito a medidas subjectivas de interesse que cristalizam vários sentidos que não se excluem entre si. São simultaneamente valores éticos e utilitaristas, de mercado e de não mercado e comensuráveis e não comensuráveis (LAMBEK, 2013). Para Lambek, "o valor dos atos performativos", à luz dos quais se pode também pensar as inúmeras formas de voluntariado, atribui um valor per si à acção, para além do bem material resultante do acto solidário. A performance no sentido de intenção e representação do acto é aquilo que distingue o acto de fazer e o acto de produzir, isto é, da dádiva e do trabalho, respectivamente. Reconciliando essas importantes nuances de inspiração maussiana e marxista (respectivamente), Lambek defende que a dádiva e o trabalho são valores inextricáveis entre si, oscilando a acção voluntária entre aqueles dois polos. Esses postulados reforçam o que se tem vindo a defender sobre o complexo processo que é o voluntariado, pois ele encerra um valor de trabalho (utilitarista e comodificável) e um valor simbólico e performático (dádiva, não comodificável). O Banco do Tempo, por exemplo, corporiza por via da sua organização (cheques, depósitos, moeda "tempo", pagamentos e recebimentos), precisamente um modelo de ajuda ao Outro, que incorpora factores instrumentais, morais e éticos.

Os processos de solidariedade informados por ideários de acção mistos (por um lado, os meramente instrumentalistas e, por outro, os mobilizadores de maior justiça social e ética global) podem ser pensados recuperando os postulados de Mauss, que referem que "uma parte considerável da nossa moral e da nossa própria vida permanece sempre nesta atmosfera da dádiva, da obrigação e ao mesmo tempo da liberdade" (MAUSS, 2008, p.195). A obrigação de retorno, proposta na teoria da dádiva "dá quanto recebes e tudo estará bem" (Ibidem, 202) observa-se nesses processos de solidariedade assentes na disponibilização de tempo próprio.

De acordo com Mauss, o propósito central da dádiva é o estabelecimento e ma-nutenção de relações sociais. Através da dádiva, o "espírito das coisas" (MAUSS, 1950) chega ao Outro e recria a relação, reconstruindo-se o factor 
mais singular das relações sociais, que é precisamente o factor social. O hau, para usar a gramática maussiana, entrega a quem recebe algo que era de quem deu. Neste caso, há uma passagem de boa vontade, de interesse e de empatia pelas preocupações e problemáticas de quem recebe, não estando o dador fora da equação (como já aqui debatemos). Essa espécie de matéria mística proposta por Mauss pode ser pensada como a causa solidária e a crença num mundo melhor, solidário, justo e, principalmente, mais equitativo. As pessoas que fazem voluntariado social também esperam (e trabalham afincadamente para isso) a disseminação dessa boa vontade e desse novo paradigma de justiça. O lema da actividade diária de uma agência da Refood é a esperança num mundo melhor e mais positivo. Neste sentido, cuidar do outro é constitutivo do laço social e um factor central nos processos de reprodução (LIMA, 2015a).

A lógica simbólica da reciprocidade nas relações sociais mostra, portanto, a complicada articulação entre as relações sociais, entre as relações entre cidadãos e o Estado, em que a assimetria e as relações de poder surgem dissimuladamente, mas se fortalecendo. A dependência dos cidadãos das redes e instituições de solidariedade intensifica-se em Portugal, quando o assistencialismo e a caridade se sobrepõem a uma política de um estado social num contexto de crise. Mas, por outro lado, vemos que esses mecanismos fazem o Estado depender da dádiva e da boa vontade dos cidadãos. As complexas inter-relações entre todos os actores nessa alargada e complexa teia de reciprocidades estabelecidas em diversas dimensões mostra diferentes níveis de dependências e de dívidas que não são apenas materiais, mas também morais, simbólicas e espirituais. É, portanto, paradoxal a forma como a mudança social ocorre em Portugal por via de uma reprodução social ancorada nessa densa e complexa teia de dádivas, numa sustentabilidade social feita através da troca voluntária de tempo. E é assim que o valor do tempo dos cidadãos imersos nessa teia adquire uma nova importância e significado, tornando-se num capital social inédito e fundamental para a manutenção dos quotidianos dos cidadãos envolvidos. 


\section{Referências}

AGAMBEN, Giorgio.

(1989). O poder Soberano e a Vida Nua Homo Sacer. Editorial Barcarena: Editorial Presença.

DEBERT, G. G.

(2013). Gênero, Velhice e Migrações. Anais VIII Congresso Latino Americano de Estudos do Trabalho, v.1. São Paulo, VIII Congresso Latino Americano de Estudos do Trabalho.

ELIAS, Norberto.

(1982). A Solidão dos Moribundos, seguido de, Envelhecer e Morrer. Rio de Janeiro: Edições Zahar.

FASSIN, Didier.

(2010). Ethics of Survival: A democratic Approach to te Politics of Life. Humanity: An Inter-national Journal of Human Rights, Humanitarian and Devolopment, v. 1, n.1, p.81-95.

FOLBRE, Nancy; Julie A. NELSON.

(2000). For Love or Money- Or Both? Journal of Economic Perspective, v. 14, n. 4, p.123- 140.

FOURNIER, Marcel.

(2003). Para rescrever a biografia de Marcel Mauss. Revista Brasileira de Ciências Sociais, 18, (52), p.5-13.

GRAEBER, David.

(2010). On the Moral Grounds if Economic Relations. A Maussian Approach. Open Anthropol-ogy Cooperative Press, Working Paper Series \#6.

HANN, Chris; Keith HART.

(2011). Economic Anthropology. History, Ethnography Critique. Cambridge: Polity Press.

HART, Keith; LAVILLE Jean-Louis; Antony CATTANI.

(2010). Building the human economy together. In: Keith Hart; Jean-Louis LaVille; Antony Cattani (Eds.); The Human Economy. A Citizen's Guide. Cambridge and Manlden: Polity Press.
KELLY, Tobias. (2013)

A life less miserable? Comment on HAN, Clara, 2012. Life in debt: Times of care and violence in neoliberal Chile. Berkeley: University of California Press. Hau: Journal of Ethnographic Theory v. 3 n. 1, p 213-216.

LAMBEK, Michael. (2013)

The value of (performative) acts. Hau: Journal of Ethnographic Theory, v. 3 n. 2, p. 141-60.

LIMA, Antónia.

(2015a) Solidariedade e caridade em tempos de crise: mutualidade, cidadania responsável, a igreja e o Estado em Portugal". In: LIMA, Antónia (org.). Cuidar do outro: Novas mutualidades e austeridade num Portugal em crise. Mundos Sociais. Lisboa, 2015.

LIMA, Antónia.

(2015). (No prelo). Cuidar em tempos de crise: Género e mudança de modos de vida em Portugal, Repensando gênero e feminismos. 20 anos do núcleo de estudos de Gênero - PAGU / Unicamp, Número comemorativo.

MARCUS, George.

(1995). Ethnography In/of the World System: The Emergence of Multi-Sited Ethnography. Annual Review of Anthropology, V. 24, p.95117.

MAUSS, Marcel.

(1950 [2008]). Ensaio sobre a Dádiva. Lisboa: Edições 70.

NAROTZKY, Susana; SMITH, Gavin.

(2006). People, Power, and Place in Rural Spain. University of California Press.

NELSON, Julie A.

(2005). Feminist Economics. In: Steven Durlauf; Lawrence Blume (Eds.); The New Palgrave Dictionary of Economics.

OLIVEIRA, Fernanda.

(2013). Solidariedade, dádiva e mercados privados numa comunidade eborense: sustentabili-dade e processos constitutivos dos agentes de cuidado. Tese de Mestrado 
apresentada ao Insti-tuto Universitário de Lisboa - ISCTE-IUL.

ORTNER, Sherry B.

(1974). Is Female to Male as Nature is to Culture?. In: Michelle Rosaldo; Louise Lamphere (Eds.). Woman, Culture and Society. Standford: Standford University Press, p.67-87.

READ, Rosie.

(2009). Nuns, Fundraising and Volunteering. The Gifting of Care in Czech Services for the Elderly and Infirm. In:Carolin LeutloffGrandits; Anja Peleikis; Tatjana Thelen (Eds.); Social Security. Oxford, England: Berghahn Books. p.128-145.
SANTOS, Boaventura S.

(1999). The Welfare State in Portugal: Between Conflicting Globalizations. Paper apresentado no Center for European Studies. Harvard University, 01 Março de 1999.

\section{Recebido em}

outubro de 2015

\section{Aprovado em}

novembro de 2015 